proposal that powers should be obtained to require firms in an industry to contribute towards cooperative research where the large bulk of the industry was in favour of such a course. The result was unfavourable to the proposal. Evidence has, however, been received that there may have been some change of opinion in the interval and the Department propose to consult the Associations again on the subject. If it appears that there is now a consensus of opinion in favour of such a Bill and if it is the opinion that a levy for research would be found practicable in a sufficient number of cases and that advantage is likely to be taken fairly generally of the provisions of such a Bill, . . . the whole matter will receive sympathetic consideration by the Government."

THIs reply is encouraging, and has an important bearing on the investigations undertaken by a Joint Committee of the British Science Guild and Association of Scientific Workers as to whether the research associations should be financed by a levy on the industries concerned, or by a State grant for a limited number of years of a sum of money designed to form an endowed capital for research-such grants to be provided from the new revenue from tariffs, wireless licences or other sources.

\section{The Panda or Cat-Bear}

THE arrival at the Gardens of the Zoological Society of London of three specimens of that rare and most interesting animal the panda, or 'cat-bear' (Aelurus fulgens), should form an addition of no small interest to those visiting the Gardens during the summer months. The coloration of this animal is striking. The fur is of a rich chestnut-red, with white markings on the head, and black rings round the conspicuously long tail, while the under parts are almost black instead of the normal white. Though strictly speaking a camivore, it is nevertheless almost omnivorous. For while small mammals and birds, eggs, insects and their larvæ form their principal diet, they also feed largely on fruit and many kinds of shoots, especially of the bamboo, of which they are said to be very fond. Having regard to their typically carnivorous dentition, this very mixed diet is noteworthy.

ThE present geographical distribution of the panda is restricted to the Himalayas from Nepal to Xunnan, at an elevation of 6,000-11,000 ft., where they haunt trees or hide among boulders as circumstances determine, emerging in the early morning and evening to forage for food. Not much is known of their habits, as may be imagined from their almost inaccessible haunts, but observations on captive specimens have revealed some interesting facts, especially in regard to their mode of sleeping. Thus at times they will curl up like a cat, turning the long tail over the head; and at times they are said to sleep standing, with the head turned downwards between the forelegs after the manner of their near relations the racoons. When excited they emit a strong odour of musk. The panda is evidently a species which is dying out, for its range in past times was vastly greater. This much is shown by the fact that a panda one and a half times larger than the existing species has been found in the English Pliocene. No fossil remains of pandas have yet been found in America. But having regard to its very near kinship with the racoons, they may yet be found.

\section{Cane-Rats}

ANoTher addition to the Zoo worthy of note is three young cane-rats (Aulacodus swinderianus) from West Africa. These animals attain a considerable size when adult, the body measuring nearly two feet in length, exclusive of the tail, and weigh as much as $10 \mathrm{lb}$. They range from the Sudan to the Cape, and up the west coast as far as Sierra Leone. The fur is conspicuously bristly, speckled with yellow and brown. The incisor teeth are of great size and very powerful. The upper pair are marked by three vertical grooves, sufficiently deep to leave their mark on anything gnawed by these animals. They feed on roots and shoots, and sugar-cane where it is to be had.

\section{Archæological Studies in Peru}

IT would appear that the celebration, or rather the 'commemoration', to use the term preferred locally, of the fourth centenary of the Spanish capture of Cuzco, the capital of the Inca empire of Peru, has given rise to a wave of popular enthusiasm for archæology which has taken the practical form of a vote of $\$ 30,000$ (according to a dispatch in the Times of March 27) to be expended on, inter alia, the establishment of an archæological institute for the study and display of Peruvian antiquities and on archæological exploration and research. Already substantial discoveries have been made in the excavation of Sachsahuaman, a site near Cuzco, where hundreds of workmen are engaged in uncovering the walls, buildings, conduits, etc., in beautifully hewn stone of this once important fortress, which has been pronounced to be the "most wonderful achievement of ancient man in the two Americas". Excavations have also been begun at Tambo-machal and Pisac, and are in contemplation at Ollantaytambo and Macchu Picchu, the last stronghold of Inca power. These operations are under the supervision of the Director General of the National Museum and are being conducted in accordance with the principles of scientific archæological research. Even at this early stage, attention has been directed to the problem of pre-Inca civilisation and the opportunities which it offers for investigation. Happily the foundations for its study on scientific lines have been laid down by the work of Prof. Max Uhle and others, and if funds which hitherto have been lacking for extended exploration are now to be available, many vexed and obscure problems of Central and South American archæology will come under review. The presence of a number of distinguished archæologists in Peru during the celebrations, which began on March 23 and will go on until July 18, will no doubt guide, as well as stimulate, local effort, which is inspired by motives not entirely unmixed. Even in Peru, archæology is not immune from the spur of over-enthusiastic nationalism. 